\title{
Fatty Acid Profile and Milk Cholesterol of Crossbred Holstein $\times$ Zebu Cows Fed on Whole Cottonseed
}

\author{
Edvaldo N. Costa, ${ }^{a}$ Sibelli P. B. Ferrão, ${ }^{b}$ Robério R. Silva, ${ }^{b}$ Antonio F. Porto Jr., ${ }^{b}$ \\ Jeanny M. A. Damásio, ${ }^{b}$ Bismark M. Santiago, ${ }^{b}$ Evely G. L. Costa ${ }^{b}$ and \\ Fabiano F. da Silva*,b

\begin{abstract}
aInstituto Federal de Educação, Ciência e Tecnologia Baiano (IFBAIANO), Campus Governador Mangabeira, Rua Waldemar Mascarenhas s/n, 44350-000 Governador Mangabeira-BA, Brazil

${ }^{b}$ Departamento de Tecnologia Rural e Animal, Universidade Estadual do Sudoeste da Bahia, Praça Primavera, 40, 45700-000 Itapetinga-BA, Brazil
\end{abstract}

\begin{abstract}
The objective of this study was to evaluate the effect of whole cottonseed on diets of cows under grazing on fatty acid profile and milk cholesterol. Five crossbred Holstein $\times$ Zebu cows were distributed in a $5 \times 5$ Latin square. Inclusion levels were $0,6,12,18$ and $24 \%$. There was a linear decrease in all fatty acids quantified, saturated and monounsaturated $(p>0.05)$, possibly due to the action of polyunsaturated fatty acids ingested in the diet. There was no influence of treatment on conjugated linoleic acids or cholesterol. It is concluded that, regardless of inclusion level, there is a modification in the milk lipid profile, reducing the concentration of saturated fatty acid, monounsaturated fatty acid, and making it rich in polyunsaturated fatty acids, which are beneficial to health.
\end{abstract}

Keywords: fat analysis, gas chromatography, liquid chromatography, conjugated linoleic acid

\section{Introduction}

Ruminant diets vary in composition, depending on species, physiological state, besides cost and availability of feed ingredients. Traditional ingredients in such formulations are commonly used, like soybeans and corn, but food industry by-products or lipid supplements may also be included. ${ }^{1}$

Regarding feed formulation, the use of by-products from various industries and agro-industries has been gaining strength in the animal production system, generating a positive impact in the field of scientific technical research, as well as assuring to milk producers a new alternative food source, frequently at a low cost, as a function of region availability. In this segment, the use of cottonseed has gained ground in research integrated with several areas, both in animal and human nutrition, and even in food engineering with animal nutrition. ${ }^{2}$

The composition of the diet is the main factor that influences the composition of fatty acids (FA) of ruminant meat and milk, since FA that reach the duodenum are,

*e-mail: ffsilvauesb@hotmail.com at least in part, of dietary origin, as well as the result of microbial biohydrogenation of the rumen of dietary lipids. ${ }^{3}$

The composition of FA from cow milk has become less favorable to human health in the last four decades, due to the change in feeding and management practices, which began to have higher proportions of concentrates and silage in diets with less grazing. Therefore, human intake of essential FA and conjugated linoleic acid (CLA) decreased, reflecting their low concentrations in ruminant milk, as well as the consumption of low-fat dairy products. ${ }^{4}$

Cholesterol in the human diet has recently attracted more attention, since it is suspected to be one of the factors that lead to atherosclerosis. Although cholesterol is synthesized in the body, dietary sources may contribute to the total amount in the cell and food selection may be a potential method to reduce the total cholesterol concentration in the body. Dairy products represent significant fractions of dietary cholesterol in the Western world. ${ }^{5}$ The fat source in the diet may have an effect on the cholesterol status of cows, especially by modulating their milk content. ${ }^{6}$ Therefore, the objective of this study was to verify the influence of cottonseed feed on the lipid profile and milk cholesterol of crossbred Holstein $\times$ Zebu cows. 


\section{Experimental}

\section{Animals and treatments}

The experiment was conducted at the State University of Southwest Bahia (UESB), Campus Itapetinga, BA, from March to June 2015.

Five crossbred Holstein $\times$ Zebu cows (blood level between $1 / 2$ to $3 / 4 \mathrm{H} \times \mathrm{Z}$ blood) were used, at the third or fourth lactation order, all with 80 to 120 days of lactation at the beginning of the experimental period. They were arranged in a $5 \times 5$ Latin square, with 5 inclusion levels of cottonseed $(0,6,12,18,24 \%)$, on a dry matter basis. Each experimental period consisted of 21 days, 16 days of adaptation to the diet and 5 days for sample collection.

The composition of the concentrate (Table S1, Supplementary Information (SI) section) was defined by the balance of the diets, to contain nutrients sufficient for maintenance, body weight gain of $0.15 \mathrm{~kg} \mathrm{day}^{-1}$ and production of $20 \mathrm{~kg}$ of milk day ${ }^{-1}$, adjusted to $4.5 \%$ of fat, according to the NRC (2001), ${ }^{7}$ and based on data from the chemical-bromatological composition of Brachiaria decumbens grass, maize, soybean meal and cottonseed, performed one week before the experimental period. The animals were placed in individual covered stalls, equipped with troughs and drinking fountains. The diets were offered to the animals in two fractions, daily, at the same time (7.00 a.m. and 2.00 p.m.).

\section{Lipid profile analysis}

The concentrate and bulk samples were also collected to determine the fatty acid profile (Table S2, SI section). Lipid extraction was based on the procedure proposed by Bligh and Dyer. ${ }^{8}$

Milk lipid extraction followed the methodology proposed by Folch et al., ${ }^{9}$ and transesterification was carried out according to Bannon et al. ${ }^{10}$ with modifications according to Simionato et al. ${ }^{11}$

FA esters were analyzed by a GC-2010 Plus Shimadzu gas chromatograph, equipped with a flame ionization detector (FID) and an Rt-2560 fused silica capillary column (100 m, 0.25 mm i.d.). Gas flow (White Martins) was $40 \mathrm{~mL} \mathrm{~min}^{-1}$ for the carrier gas $\left(\mathrm{H}_{2}\right) ; 30 \mathrm{~mL} \mathrm{~min}^{-1}$ for the auxiliary gas $\left(\mathrm{N}_{2}\right)$ and $4000 \mathrm{~mL} \mathrm{~min}^{-1}$ for the synthetic air flame. The sample split ratio was 90:10. The operating parameters were established after verification of the best resolution conditions. The injector and detector temperatures were 225 and $260{ }^{\circ} \mathrm{C}$, respectively. The column temperature was programmed at $140{ }^{\circ} \mathrm{C}$ for $5 \mathrm{~min}$, followed by a ramp of $3{ }^{\circ} \mathrm{C} \mathrm{min}^{-1}$ to reach $245{ }^{\circ} \mathrm{C}$ for
$20 \mathrm{~min}$. The total analysis time was $60 \mathrm{~min}$. Injections were performed in duplicate and injection volume was $0.7 \mu \mathrm{L}$. The peak areas of FA methyl esters were determined using the LCSolution ${ }^{\circledR}$ software.

Identification and quantification of fatty acids

The identification of FA was performed after verifying the equivalent peak chain length and comparing the retention times of fatty acid methyl ester (FAME) standards containing the c9t11 and t10c12 isomers of linoleic acid (189-19 and O-5626, Sigma-Aldrich ${ }^{\circledR}$ ), as described by Simionato et al. ${ }^{11}$

The quantification of FA, in $\mathrm{mg} \mathrm{g}^{-1}$ total lipids, was performed in relation to the internal standard, methyl tricosanoate (23:0), Sigma-Aldrich ${ }^{\circledR}$. Calculations of fatty acid concentration in the samples were performed according to Joseph and Ackman. ${ }^{12}$

The agreement between theoretical and experimental response factors was verified, as described by Simionato et al. ${ }^{11}$

\section{Extraction and quantification of milk cholesterol}

The extraction, detection, identification and quantification of cholesterol was performed following the methodology of Bauer et al. ${ }^{13}$

For sample analysis, a liquid chromatograph (Shimadzu) was used, equipped with a quaternary system of pumps, degasser, injection valve with a $20 \mathrm{~L}$ sampling handle, column furnace and a diode array detector. Cholesterol was separated on a $\mathrm{C} 18$ reverse phase column (15 cm $\times 6 \mathrm{~mm}$ i.d. $\times 5 \mathrm{~m}$, Restek). For the mobile phase, solvents with a chromatographic grade were used: acetonitrile and isopropanol at a ratio of 95:5 (v/v), which were filtered and degassed before the chromatographic runs. The operating parameters of the chromatograph were established in: flow adjusted to $2 \mathrm{~mL} \mathrm{~min} \mathrm{~m}^{-1}$, oven temperature at $35{ }^{\circ} \mathrm{C}$ and running time of $15 \mathrm{~min}$. Injections were performed in duplicate and the peak areas of cholesterol were determined using the LCSolution ${ }^{\circledR}$ software.

Cholesterol was tentatively identified by comparing the peak retention time of the samples with the peak retention time of cholesterol (cholesterol, code C8667, Sigma-Aldrich $^{\circledR}$ ) and the characteristic wavelength of the substance. The chromatogram was run at $202 \mathrm{~nm}$.

\section{Statistical analysis}

Data were evaluated through analysis of variance and regression, using the program Statistical Analysis 
System (SAS, 2003). ${ }^{14}$ The statistical models were chosen according to the significance of the regression coefficients, using the $F$-test at $5 \%$ probability and coefficient of determination $\left(\mathrm{R}^{2}\right)$.

\section{Results and Discussion}

Twenty-six fatty acids were identified and quantified (according to the chromatogram, Figure S1, SI section), and the results were expressed as milligrams of fatty acid per gram of fat, and grouped according to saturation: saturated (SFA) (Table 1), monounsaturated (MFA) and polyunsaturated (PUFA) (Table 2). In all samples, the fatty acids found at greater amounts were palmitic (16:0), oleic (18:1n-9c) and stearic (18:0), with mean percentages of $30.04 ; 22.50$ and $16.93 \%$, respectively.

Table 1. Saturated fatty acids in milk of lactating cows fed with different levels of cottonseed

\begin{tabular}{|c|c|c|c|c|c|c|c|c|c|}
\hline \multirow{2}{*}{\multicolumn{2}{|c|}{ Fatty acid $/\left(\mathrm{mg} \mathrm{g}^{-1}\right)$}} & \multicolumn{5}{|c|}{ Level of cottonseed / \% DM } & \multirow{3}{*}{$\begin{array}{c}\hat{\mathrm{Y}}^{\mathrm{b}} \\
14.77\end{array}$} & \multirow{3}{*}{$\frac{\mathrm{CV}^{\mathrm{c}} / \%}{4.43}$} & \multirow{3}{*}{$\begin{array}{c}\mathrm{P}^{\mathrm{d}} \\
+17.50 ; \mathrm{R}^{2}=0.853\end{array}$} \\
\hline & & \multirow{2}{*}{$\frac{0}{18.56}$} & \multirow{2}{*}{$\frac{6}{14.85}$} & \multirow{2}{*}{$\frac{12}{14.77}$} & \multirow{2}{*}{$\frac{18}{13.08}$} & \multirow{2}{*}{$\frac{24}{12.61}$} & & & \\
\hline Butyric & $4: 0$ & & & & & & & & \\
\hline Caproic & $6: 0$ & 8.52 & 7.61 & 6.47 & 6.56 & 6.34 & 7.1 & 7.00 & $\mathrm{y}=-0.090 \mathrm{x}+8.182 ; \mathrm{R}^{2}=0.826$ \\
\hline Caprylic & $8: 0$ & 5.20 & 4.31 & 3.86 & 3.52 & 3.43 & 4.06 & 12.44 & $y=-0.072 x+4.93 ; R^{2}=0.896$ \\
\hline Capric & $10: 0$ & 12.89 & 9.48 & 9.27 & 7.05 & 6.49 & 9.03 & 7.95 & $y=-0.253 x+12.08 ; R^{2}=0.908$ \\
\hline Undecylic & $11: 0$ & 1.42 & 1.12 & 0.99 & 0.68 & 0.94 & 1.03 & 12.89 & $\mathrm{y}=-0.023 \mathrm{x}+1.31 ; \mathrm{R}^{2}=0.670$ \\
\hline Lauric & $12: 0$ & 13.96 & 10.95 & 9.75 & 7.92 & 6.75 & 9.86 & 12.11 & $y=-0.290 x+13.35 ; R^{2}=0.968$ \\
\hline Myristic & $14: 0$ & 50.72 & 43.23 & 38.21 & 36.40 & 35.05 & 40.72 & 4.70 & $y=-0.636 x+48.35 ; R^{2}=0.891$ \\
\hline Pentadecenoic & $15: 0$ & 4.92 & 4.16 & 3.71 & 3.66 & 2.70 & 3.83 & 9.13 & $y=-0.082 x+4.818 ; R^{2}=0.932$ \\
\hline Palmitic & $16: 0$ & 139.35 & 117.91 & 107.93 & 102.61 & 96.31 & 112.82 & 3.62 & $y=-1.689 x+133.1 ; R^{2}=0.909$ \\
\hline Margaric & $17: 0$ & 6.37 & 5.04 & 4.45 & 3.56 & 2.49 & 4.38 & 17.69 & $y=-0.154 x+6.23 ; R^{2}=0.987$ \\
\hline Stearic & $18: 0$ & 73.85 & 64.40 & 61.77 & 60.46 & 55.83 & 63.26 & 8.58 & $y=-0.644 x+70.99 ; R^{2}=0.836$ \\
\hline Arachidic & $20: 0$ & 0.487 & 0.42 & 0.37 & 0.35 & 0.27 & 0.37 & 11.54 & $y=-0.008 x+0.480 ; R^{2}=0.971$ \\
\hline Heneicosylic & $21: 0$ & 0.77 & 0.64 & 0.55 & 0.58 & 0.45 & 0.59 & 20.61 & $y=-0.011 x+0.738 ; R^{2}=0.876$ \\
\hline Behenic & $22: 0$ & 0.11 & 0.056 & 0.057 & 0.058 & 0.051 & 0.06 & 18.44 & $y=-0.001 x+0.089 ; R^{2}=0.559$ \\
\hline
\end{tabular}

${ }^{\mathrm{a} U s u a l}$ nomenclature; ${ }^{\mathrm{b}}$ mean; ${ }^{\mathrm{c}}$ coefficient of variation; ${ }^{\mathrm{d}}$ regression equation. DM: dry matter; $\mathrm{R}^{2}$ : coefficient of determination.

Table 2. Mono and polyunsaturated fatty acids in milk of lactating cows fed with different levels of cottonseed

\begin{tabular}{|c|c|c|c|c|c|c|c|c|c|}
\hline \multirow{2}{*}{ Fatty acid ${ }^{\mathrm{a}}$} & & \multicolumn{5}{|c|}{ Level of cottonseed / \% DM } & \multirow{2}{*}{$\hat{\mathrm{Y}}^{\mathrm{b}}$} & \multirow{2}{*}{$\mathrm{CV}^{\mathrm{c}} / \%$} & \multirow{2}{*}{$\mathrm{P}^{\mathrm{d}}$} \\
\hline & & 0 & 6 & 12 & 18 & 24 & & & \\
\hline \multicolumn{10}{|c|}{ Monounsaturated / $\left(\mathrm{mg} \mathrm{g}^{-1}\right)$} \\
\hline Myristoleic & $14: 1$ & 5.40 & 4.47 & 3.74 & 2.54 & 2.28 & 3.68 & 10.87 & $y=-0.136 x+5.32 ; R^{2}=0.975$ \\
\hline Pentadecenoic & $15: 1$ & 1.04 & 0.88 & 0.84 & 0.79 & 0.67 & 0.84 & 12.82 & $\mathrm{y}=-0.013 \mathrm{x}+1.01 ; \mathrm{R}^{2}=0.944$ \\
\hline Palmitoleic & $16: 1$ & 3.24 & 2.94 & 2.85 & 2.46 & 2.38 & 2.77 & 14.22 & $y=-0.036 x+3.214 ; R^{2}=0.959$ \\
\hline Heptadec-10-enoic acid & $17: 1$ & 1.17 & 0.97 & 0.89 & 0.83 & 0.74 & 0.92 & 9.82 & $\mathrm{y}=-0.016 \mathrm{x}+1.12 ; \mathrm{R}^{2}=0.939$ \\
\hline Elaidic & $18: \ln 9 \mathrm{t}$ & 6.91 & 3.75 & 2.94 & 2.19 & 1.59 & 3.47 & 19.74 & $y=-0.203 x+5.916 ; R^{2}=0.857$ \\
\hline Oleic & $18: \ln 9 \mathrm{c}$ & 97.05 & 93.71 & 86.65 & 82.49 & 63.06 & 84.59 & 3.63 & $y=-1.32 x+100.4 ; R^{2}=0.882$ \\
\hline \multicolumn{10}{|c|}{ Polyunsaturated / $\left(\mathrm{mg} \mathrm{g}^{-1}\right)$} \\
\hline Gamma-linoleic & $18: 2 n-6$ & 1.36 & 1.36 & 1.36 & 1.36 & 1.36 & 1.36 & 6.69 & 1.00 \\
\hline$\gamma$-Linolenic acid & $18: 3 n-6$ & 4.62 & 4.62 & 4.62 & 4.62 & 4.60 & 4.61 & 4.68 & 1.00 \\
\hline Dihomo-gamma-linolenic acid & $20: 3 n-6$ & 0.28 & 0.28 & 0.28 & 0.28 & 0.29 & 0.28 & 8.16 & 1.00 \\
\hline Eicosatrienoic acid & $20: 3 n-3$ & 0.34 & 0.34 & 0.34 & 0.34 & 0.33 & 0.33 & 15.15 & 1.00 \\
\hline Conjugated linoleic acid & $18: 2 \mathrm{c} 9 \mathrm{t} 11$ & 0.72 & 0.71 & 0.71 & 0.72 & 0.73 & 0.71 & 13.40 & 1.00 \\
\hline Conjugated linoleic acid & $18: 2 \mathrm{t} 10 \mathrm{c} 12$ & 0.42 & 0.43 & 0.41 & 0.42 & 0.42 & 0.42 & 19.81 & 1.00 \\
\hline
\end{tabular}

${ }^{\mathrm{a}}$ Usual nomenclature; ${ }^{\mathrm{b}}$ mean; ${ }^{\mathrm{c}}$ coefficient of variation; ${ }^{\mathrm{d}}$ regression equation. DM: dry matter; $\mathrm{R}^{2}$ : coefficient of determination. 
Cottonseed contains an average of 26.4 and $72.9 \%$ of saturated and unsaturated fatty acids, respectively. ${ }^{15}$ The diet with the addition of increasing cottonseed levels leads to an increase in the intake of unsaturated fatty acids (UFA) in cows, as observed in Table S2 (SI section), where it is possible to verify that the increase in the percentage of cottonseed in the formulations caused an increase in their UFA values. Lipid supplementation for lactating cows causes changes in milk composition, depending on the milk source and level. ${ }^{16}$

The results of this study point to a linear decreasing effect of saturated fatty acids (SFA) quantified in relation to cottonseed levels $(p<0.05)$. UFA are potent inhibitors of fatty acid synthesis in the mammary gland through a direct inhibitory effect on the activity of acetyl-CoA carboxylase. ${ }^{17}$ When these FA are available, there is a decrease in the percentage of SFA in milk fat. ${ }^{18}$ Soita et al. ${ }^{19}$ and Solórzano and Ruiz ${ }^{20}$ evaluated the feeding of milk cows with oilseeds, and found similar results regarding the reduction of short and medium chain SFA ( $\mathrm{C} 4: 0$ to $\mathrm{C} 16: 0)$, corroborating the data found in this study.

The FA with an odd number of carbon chains (C11:0; $\mathrm{C} 15: 0 ; \mathrm{C} 17: 0 ; \mathrm{C} 21: 0)$, as well as the others, were reduced with increased cottonseed levels in the $\operatorname{diet}(p<0.05)$. Their concentration is attributed to the variation between the amount of starch/fiber in the diet, concomitantly reducing dietary starch and increasing the lipid content in the diet. ${ }^{21,22}$

As for MFA (Table 2), there was a decreasing linear effect $(p<0.05)$, which can be explained by the fact that
$\Delta 9$-desaturase acts predominantly in MFA synthesis, desaturating SFA with 14 to 18 carbons, converting them into their corresponding monounsaturated acids. ${ }^{23,24}$ The activity of $\Delta 9$-desaturase can be indirectly evaluated through four main indices, obtained through the relationship between FA pairs represented by the products $(14: 1 \mathrm{n}-9 \mathrm{c}$, 16:1n-9c, 18:1n-9c and CLA cis-9, trans-11) and substrates (14:0, 16:0, 18:0 and 18:1n7t) of the enzyme. ${ }^{25}$ Among these, the best indicator of $\Delta 9$-desaturase activity is the ratio C14:1:C14:0, since all C14:0 in milk fat is produced by the synthesis in the mammary gland and, consequently, desaturation is the only source of C14:1.26 As there was a reduction in the levels of MFA and their respective precursors, for example C14:1/C14:0; C16:1/C16:0, the data demonstrated a significant linear reduction (Table 3), referring to the activity of $\Delta 9$-desaturase.

In relation to the fatty acids of the omega- 6 (18:2n-6; 18:3n-6; 20:3n-6) and omega-3 (20:3n-3) families, no effect was observed among the treatments and they should be obtained from plant materials in the diet. ${ }^{27}$

In humans, omega- 3 and omega- 6 are required to maintain normal cell membrane, brain function and nerve impulse transmission under normal conditions, and are considered essential for mammals..$^{24,28}$

There was no difference in the concentration of CLA (Table 2) in milk fat, which may be due to the non-interference of treatments in linoleic and linolenic acids (Table 2), since CLA originate from biohydrogenation. ${ }^{29,30}$ The isomer 18:2c9t11 represented the highest CLA content

Table 3. Mean values for total fatty acids, $\Delta 9$-desaturase enzyme activity and cholesterol for raw milk samples

\begin{tabular}{|c|c|c|c|c|c|c|c|c|}
\hline \multirow{2}{*}{ Fatty acid } & \multicolumn{5}{|c|}{ Levels of cottonseed / \% DM } & \multirow{2}{*}{$\hat{\mathrm{Y}}^{\mathrm{a}}$} & \multirow{2}{*}{$\mathrm{CV}^{\mathrm{b}} / \%$} & \multirow{2}{*}{$\mathrm{P}^{\mathrm{c}}$} \\
\hline & 0 & 6 & 12 & 18 & 24 & & & \\
\hline \multicolumn{9}{|c|}{ Total / $\left(\mathrm{mg} \mathrm{g}^{-1}\right)$} \\
\hline Saturated $^{\mathrm{d}}$ & 337.87 & 284.82 & 262.53 & 247.13 & 230.34 & 272.53 & 3.42 & $y=-4.212 x+323.0 ; R^{2}=0.919$ \\
\hline Monounsaturated $^{\mathrm{e}}$ & 114.84 & 106.74 & 97.94 & 91.33 & 70.75 & 96.32 & 2.32 & $y=-1.726 x+117.0 ; R^{2}=0.947$ \\
\hline Polyunsaturated $^{\mathrm{f}}$ & 8.94 & 9.14 & 9.14 & 9.14 & 9.75 & 9.22 & 3.89 & $y=0.027 x+8.898 ; R^{2}=0.693$ \\
\hline$n-6^{g}$ & 6.27 & 6.27 & 6.28 & 6.27 & 6.26 & 6.27 & 3.57 & $0.99^{1}$ \\
\hline$n-3^{h}$ & 0.341 & 0.342 & 0.345 & 0.343 & 0.337 & 0.34 & 15.15 & $0.99^{1}$ \\
\hline PUFA/SFA ${ }^{\mathrm{i}}$ & 0.026 & 0.032 & 0.034 & 0.036 & 0.042 & 0.034 & 4.55 & $y=0.000 x+0.026 ; R^{2}=0.952$ \\
\hline$n-6 / n-3^{j}$ & 18.86 & 19.28 & 18.65 & 18.32 & 19.06 & 18.83 & 13.16 & $0.97^{1}$ \\
\hline \multicolumn{9}{|c|}{ Desaturase index ${ }^{k}$} \\
\hline $14: 1$ & 0.096 & 0.093 & 0.089 & 0.065 & 0.061 & 0.08 & 7.43 & $\mathrm{y}=-0.001 \mathrm{x}+0.100 ; \mathrm{R}^{2}=0.882$ \\
\hline \multicolumn{9}{|c|}{ Cholesterol / (mg $\left.100 \mathrm{~mL}^{-1}\right)$} \\
\hline Cholesterol & 5.94 & 4.45 & 5.11 & 4.72 & 6.24 & 5.29 & 35.03 & 0.51 \\
\hline
\end{tabular}


in the samples (63\%), when compared to the other linoleic acid isomer (18:2t10c12) observed, which was already expected to be the main isomer found in ruminant fat. ${ }^{31}$

The diet is one of the main determinants of CLA content in milk fat, but the individual variations of each cow should also be considered..$^{32}$ The endogenous system accounts for $78 \%$ of the total 18:2c9t11 in milk fat. Thus, endogenous synthesis is the main source of $18: 2 \mathrm{c} 9 \mathrm{t} 11$ in milk fat of lactating cows ${ }^{26}$ which indicates that the animal factor is the predominant factor in the production of this fatty acid.

Nunes and Torres $^{33}$ estimated that the CLA intake by the Brazilian population is $36 \mathrm{mg}$ day $^{-1}$, using cow milk and its derivatives (prato cheese and butter) as source foods. Ritzenthaler et $a l .{ }^{34}$ estimated, through a food frequency record, that the daily intake of CLA by westerners is approximately $200 \mathrm{mg} \mathrm{day}^{-1}$. Considering that the average observed for $18: 2 \mathrm{c} 9 \mathrm{t} 11$ was $0.71 \mathrm{mg} \mathrm{g}^{-1}$, and if a consumer consumes one glass of milk a day, they will consume $213 \mathrm{mg} \mathrm{day}^{-1}$ of 18:2c9t11, which equals a value higher than that found by Ritzenthaler et al. ${ }^{34}$ and that estimated by Nunes and Torres. ${ }^{33} \mathrm{It}$ is worth noting that the calculation refers to the consumption of fresh milk, but, according to Costa et al. ${ }^{35}$ there is no statistical difference in CLA levels in fresh and pasteurized milk, which allows to say that the consumption of a microbiologically safer milk maintains the same CLA levels as fresh milk.

Part of the results presented in Table 3 (sums of SFA, MFA and PUFA) are commercially favorable. With consumers increasingly concerned about health, a product that has a reduction in SFA is attractive, since this factor favors the reduction in blood cholesterol in humans. ${ }^{36}$ Lacerda et al. ${ }^{37}$ concluded that a PUFA-rich diet provided to crossbred Holstein $\times$ Zebu cows does not alter the sensory characteristics of milk.

The ratio of PUFA and SFA showed a linear increasing effect $(p<0.01)$, with a mean of $0.034 \mathrm{mg} \mathrm{g}^{-1}$ among treatments. For the UK Department of Health, ${ }^{38}$ the ideal value of this ratio for food to be considered healthy should be 0.40 . In dairy products, low values for this ratio are already expected, since ruminant fat has a higher amount of SFA and a lower ratio for PUFA and MFA, as a function of PUFA biohydrogenation in the rumen diet by the action of microorganisms..$^{39}$ Even though in this experiment there was an influence on biohydrogenation, the ratio was below than the value of English organism.

The ratio of n-6/n-3 was not statistically altered with the inclusion of different cottonseed levels to the diet, and a mean value of 18.83 was found. These values do not fall within the recommendation of the United States Department of Agriculture, ${ }^{40}$ which suggests that it should be between 5 and 10, thus noting that the inclusion of cottonseed has impaired the ratios for these fatty acids. However, these values for dairy products are already high.

There was no influence of treatments on the concentration of milk cholesterol, and the values found in this study are similar to the average values found by Bauer et al. ${ }^{41}$ evaluating the inclusion of oregano levels on milk cholesterol content (5.66 mg $\left.100 \mathrm{~mL}^{-1}\right)$. These values differ from those reported by Faye et al. ${ }^{6}$ who found cholesterol levels ranging from 8.51 to $9.07 \mathrm{mg} 100 \mathrm{~mL}^{-1}$ in cow milk.

The per capita milk consumption under Brazilian inspection is 2 glasses inhabitant ${ }^{-1}$ day $^{-1},{ }^{42}$ and the average

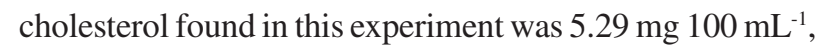
which generates a consumption of $25.12 \mathrm{mg} 100 \mathrm{~mL}^{-1}$, below the $300 \mathrm{mg} 100 \mathrm{~mL}^{-1}$ recommended by Lichtenstein et al., ${ }^{43}$ indicating that the milk of the experiment has good characteristics regarding the analyzed item.

\section{Conclusions}

From the data obtained in this study, it was concluded that whole cottonseed, independent of the level applied to the diet in this experiment, modified the lipid profile of milk, conferring good nutritional characteristics, as there was a quantitative reduction in saturated and monounsaturated fatty acids, besides an increase in polyunsaturated fatty acids. Cholesterol levels remained unchanged, regardless of inclusion level.

\section{Supplementary Information}

Additional information as proportions of concentrate ingredients, based on dry matter for lactating cows fed with different levels of cottonseed; lipid profile of the simulated and concentrate pasture consumed; gas chromatogram obtained for milk samples, and the lipid profile, are available free of charge at http://jbcs.sbq.org.br as PDF file.

\section{Acknowledgments}

The authors thank to Instituto Federal de Educação, Ciência e Tecnologia Baiano (IFBAIANO) and Programa de Pós Graduação em Zootecnia (UESB).

\section{References}

1. Shingfield, K. J.; Wallace, R. J.; Synthesis of Conjugated Linoleic Acid in Ruminants and Humans; Royal Society of Chemistry: London, UK, 2014.

2. Imaizumi, H.; Santos, F. A. P.; Bittar, C. M. M.; Correia, P. S.; Martinez, J. C.; Sci. Agric. 2010, 67, 16. 
3. Buccioni, A.; Decandia, M.; Minieri, S.; Molle, G.; Cabiddu, A.; Anim. Feed Sci. Technol. 2012, 174, 1.

4. Elgersma, A.; Tamminga, S.; Ellen, G.; Anim. Feed Sci. Technol. 2006, 131, 207.

5. Larsen, T.; Food Chem. 2012, 135, 1261.

6. Faye, B.; Bengoumi, M.; Al-Masaud, A.; Konuspayeva, G. J.; J. King Saud Univ. Sci. 2015, 27, 168.

7. National Research Council (NRC); Nutrient Requeriments of Dairy Cattle, $7^{\text {th }}$ ed.; National Academy Press: Washington, D. C., 2001.

8. Bligh, E. G.; Dyer, W.; Can. J. Biochem. Physiol. 1959, 37, 911.

9. Folch, J.; Lees, M.; Stanley, G. H. S.; J. Biol. Chem. 1957, 226, 497.

10. Bannon, C. D.; Craske, J. D.; Hai, N. T.; Harper, N. L.; O'Rourke, K. L.; J. Chromatogr. A 1982, 247, 71.

11. Simionato, J. I.; Garcia, J. C.; dos Santos, G. T.; Oliveira, C. C.; Visentainer, J. V.; Souza, N. E.; J. Braz. Chem. Soc. 2010, 21, 520.

12. Joseph, J. D.; Ackman, R. G.; J. AOAC Int. 1992, 75, 488.

13. Bauer, L. C.; Santana, D. A.; Macedo, M. S.; Torres, A. G.; Souza, N. E.; Simionato, J. I.; J. Braz. Chem. Soc. 2014, 25, 161.

14. Statistical Analysis System, Release 9.1; SAS, Inc.: Cary, USA, 2003.

15. Gondim-Tomaz, R. M. A.; Erismann, N. M.; Cia, E.; Kondo, J. I.; Fuzatto, M. G.; Carvalho, C. R. L.; Braz. J. Food Technol. 2016, 19, e2015071.

16. Palmquist, D. L.; Jenkins, T. C.; J. Dairy Sci. 1980, 63, 1.

17. Barber, M. C.; Clegg, R. A.; Travers, M. T.; Vernon, R.; Biochim. Biophys. Acta 1997, 1347, 101.

18. Fernandes, M. F.; Queiroga, R. C. R. E.; Medeiros, A. N.; Costa, R. G.; Bomfim, M. A. D.; Braga, A. A.; Rev. Bras. Zootec. 2008, 37, 703.

19. Soita, H. W.; Meier, J. A.; Fehr, M.; Yu, P.; Christensen, D. A.; Mckinon, J. J.; Mustafa, A. F.; Arch. Anim. Nutr. 2003, 57, 107.

20. Solórzano, L. A. R.; Ruiz, N. F. D.; Rev. Cienc. Agro. 2015, $1,123$.

21. Vlaeminck, B.; Fievez, V.; Cabrita, A. R. J.; Fonseca, A. J. M.; Dewhurst, R. J.; Anim. Feed Sci. Technol. 2006, 131, 389.

22. Vlaeminck, B.; Fievez, V.; Van Laar, H.; Demeyer, D.; J. Anim. Physiol. Anim. Nutr. 2004, 88, 401.

23. Mosley, E. E.; Powell, G. L.; Riley, M. B.; Jenkins, T. C.; J. Lipid Res. 2002, 43, 290.

24. Martin, C. A.; Almeida, V. V. D.; Ruiz, M. R.; Visentainer, J. E. L.; Matshushita, M.; Souza, N. E. D.; Visentainer, J. V.; Rev. Nutr. 2006, 19, 761.

25. Fox, P. F.; McSweeney, P. L. H.; Dairy Chemistry and Biochemistry; Blackie Academic \& Professional: London, 1998.

26. Corl, B. A.; Baumgard, L. H.; Dwyer, D. A.; Griinari, J. M.; Phillips, B. S.; Bauman, D. E.; J. Nutr. Biochem. 2001, 12, 622.
27. Ratnayake, W. N.; Galli, C.; Ann. Nutr. Metab. 2009, 55, 8.

28. Arterburn, L. M.; Hall, E. B.; Oken, H.; Am. J. Clin. Nutr. 2006, 83, S1467.

29. Castro, T.; Manso, T.; Jimeno, V.; Del Alamo, M.; Mantecón, A. R.; Small Rumin. Res. 2009, 84, 47.

30. Khanal, R. C.; Dhiman, T. R.; Boman, R. L.; Livest. Sci. 2008, $114,164$.

31. Mourão, D. M.; Monteiro, J. B. R.; Stringheta, P. C.; Minim, V. P. R.; Dias, C. M. G. C.; Rev. Nutr. 2005, 18, 391.

32. Rego, O. A.; Portugal, P. V.; Sousa, M. B.; Rosa, H. J.; Vouzela, C. M.; Borba, A. E.; Bessa, R. J.; Anim. Res. 2004, 53, 213.

33. Nunes, J. C.; Torres, A. G.; J. Food Compos. Anal. 2010, 23 , 782.

34. Ritzenthaler, K. L.; McGuire, M. K.; Falen, R.; Shultz, T. D.; Dasgupta, N.; McGuire, M. A.; J. Nutr. 2001, 131, 1548.

35. Costa, E. N.; Lacerda, E. C.; Santos, S.; Santos, C.; Franco, M.; Silva, R. R.; Simionato, J. I.; J. Braz. Chem. Soc. 2011, 22, 2115 .

36. Santos, R. D.; Gagliardi, A. C. M.; Xavier, H. T.; Magnoni, C. D.; Cassani, R.; Lottenberg, A. M. P.; Casella Filho, A.; Araújo, D. B.; Cesena, F. Y.; Alves, R. J.; Fenelon, G.; Nishioka, S. A. D.; Faludi, A. A.; Geloneze, B.; Scherr, C.; Kovacs, C.; Tomazzela, C.; Carla, C.; Barrera-Arellano, D.; Cintra, D.; Quintão, E.; Nakandakare, E. R.; Fonseca, F. A. H.; Pimentel, I.; Santos, J. E.; Bertolami, M. C.; Rogero, M.; Izar, M. C.; Nakasato, M.; Damasceno, N. R. T.; Maranhão, R.; Cassani, R. S. L.; Perim, R.; Ramos, S.; I Diretriz sobre o Consumo de Gorduras e Saúde Cardiovascular, vol. 100, No. 1, Suplemento 3; Arquivos Brasileiros de Cardiologia: Rio de Janeiro, 2013.

37. Lacerda, E. C. Q.; Bauer, L. C.; Oliveira, J. S.; Silva, F. F.; Carvalho, S. A.; Macedo, M. S.; Souza, N. E.; Simionato, J. I.; Anim. Feed Sci. Technol. 2014, 192, 101.

38. United Kingdom Department of Health, Committee on Medical Aspects of Food Policy; Nutritional Aspects of Cardiovascular Disease, Report on Health and Social Subjects, No. 46; HMSO: London, 1994.

39. French, P.; Stanton, C.; Lawless, F.; O’Riordan, E. G.; Monahan, F. J.; Caffrey, P. J.; J. Anim. Sci. 2000, 78, 2849.

40. World Health Organization; Rev. Nutr. 1995, 53, 202.

41. Bauer, L. C.; Lacerda, E. C. Q.; Damasio, J. M. A.; Macedo, M. S.; Santos, S. M. S.; Santos, C. M. S.; Santana, D. A.; Simionato, J. I.; Hig. Aliment. 2013, 27, 1088.

42. http://www.conab.gov.br/OlalaCMS/uploads/ arquivos/16_05_04_17_33_34_leite_abril_2016.pdf, accessed on February 15, 2017.

43. Lichtenstein, A. H.; Appel, L. J.; Brands, M.; Carnethon, M.; Daniels, S.; Franch, H. A.; Circulation 2006, 114, 82.

Submitted: November 13, 2017

Published online: March 19, 2018 